\title{
THE ANALYSIS OF CAPITAL BUDGETING TECHNIQUES IMPLEMENTED BY SMALL AND MEDIUM-SIZED ENTERPRISES IN SERBIA
}

\author{
Lidija Barjaktarović ${ }^{\star}$, Renata Pindžo, Katarina Đulić, Ana Vjetrov \\ Singidunum University, Faculty of Business in Belgrade, 32 Danijelova Street, Belgrade, Serbia
}

\begin{abstract}
:
In this paper, the authors examine current practices in investment decision-making on a sample of 30 small and medium-sized enterprises in Serbia. The survey included small and medium-sized enterprises (SMEs) and micro companies. The questionnaire was filled out by the chief financial officers (CFOs) in order to obtain relevant results.

Small and medium-sized enterprises play an important role in the economic development of any country, and are the main generator of economic growth in the EU countries. Therefore, this paper aims to examine their role in Serbia, their contribution to reducing unemployment rates and analyse investments of the surveyed enterprises. Furthermore, the authors shall attempt to identify most frequently used capital budgeting techniques in small, micro and medium-sized companies in Serbia when evaluating investment projects. Finally, the precise investment policy of an enterprise represents the key factor for achieving feasible and sustainable investments, approved and chosen by means of various capital budgeting methods. Consequently, their role in everyday business operations of SMEs and micro companies is relevant for the analysis, especially within the conditions of economic turmoil. A well-defined investment policy plays an important role in achieving successful and sustainable capital investments in the long run, which would enable small and medium-sized enterprises to become important generators of economic growth in Serbia.
\end{abstract}

\section{Key words:}

investment policy, economic growth, small and medium-sized enterprises, capital budgeting techniques.

\section{Acknowledgment:}

This research paper is part of the project entitled “Advancing Serbia's Competitiveness in the Process of EU Accession”, No. 47028, for the period 2011-2015, financed by the Ministry of Education, Science and Technological Development.

\section{INTRODUCTION}

Small and medium-sized enterprises (SMEs) are defined by the European Commission as the entities having less than 250 persons employed, annual turnover of up to EUR 50 million, or the balance sheet totaling no more than EUR 43 million (Commission Recommendation as of May 06, 2003). According to the data acquired from the European Commission site, they represent $99 \%$ of all businesses in the EU (European Union). Furthermore, they play an important role in developed countries, greatly contributing to the unemployment rate reduction. For instance, according to the Report on the small firms in the UK for the period from 2010-2015, there are currently 5.2 million small firms operating in the UK and they account for $48 \%$ of employment and 33\% of private sector turnover. These figures only enhance their role in achieving of the goals set forth in the document Europe 2020 (A strategy for smart, sustainable and inclusive growth), which was published by the European Commission as a response to economic turmoil triggered by the financial crisis. This document emphasized the importance of smart growth (developing an economy based on knowledge and innova- tion), sustainable growth (promoting a more resource efficient, greener and more competitive economy) and inclusive growth (fostering a high-employment economy delivering social and territorial cohesion). The role of small companies was in gaining a growing importance in the past years and $\mathrm{EU}$ funding programs were initiated in order to promote entrepreneurship, improve SMEs' access to markets by cutting red tape and removing the obstacles for their financing. Having in mind that Serbia aims to be an integral part of the EU, these goals should be achieved within our economy as well, fostering the growth and development of SMEs.

By analyzing the Serbian labor market, the unemployment rate went up to $17.3 \%$ at the end of 2014 (Labor Force Survey, 2015). Furthermore, the same data showed that at the end of the second quarter of 2015, the unemployment rate remained at approximately the same level, i.e. $17.9 \%$. Having analyzed the deeper structure regarding these figures, the results show that the unemployment rate for the people aging from 25-34 amounted to $34 \%$ in the second quarter of 2015. These results reveal unused potential within the Serbian economy that may significantly contribute to the Serbian economic growth. Bearing in mind that SMEs in Serbia represent 
$99.8 \%$ of the total number of entities operating in Serbia, the strengthening of the institutional environment that fosters and enables SME's growth may result as an effective way to reduce these figures regarding the youth unemployment (Eric et al., 2012). The Government's adoption of the Strategy on SMEs development in May 2015 may be a positive signal for SMEs, but it should be followed by its actual implementation in everyday business life.

Bearing in mind the importance of investments for the company's growth, our research attempts to determine the main techniques used by the sampled small, medium-sized and micro companies in investment project calculation. It is important to stress out that having in mind the importance of entrepreneurship and its development in Serbia, apart from SMEs, micro enterprises will also be covered by our analysis. The aim of this paper is to determine the most frequent investment criteria used by SMEs and micro companies when evaluating projects and ways of determining the cost of capital. The hypothesis herein tested are:

H1: The micro, small and medium-sized companies in Serbia use payback criterion as the most dominant investment evaluation technique.

H2: The micro, small and medium-sized companies in Serbia are mostly inclined to determine the cost of capital following the historical returns on investments.

This paper will be structured as follows. Within the first section, we shall present literature review along with relevant findings of similar surveys in different countries and regions. The second section presents the methodology, with a detailed description of our questionnaire. The third section presents and elaborates on the results obtained, whereas the final sections presents conclusions and relevant literature.

\section{LITERATURE REVIEW}

In previous years, these issues have been vastly explored in the literature. For instance, Graham et al. (2001) used the sample consisting of 4,440 companies and 392 chief financial officers (CFOs) that participated in the survey in the USA (The United States of America) and Canada. The main conclusion was that most of the samples firms used the present value techniques for evaluating new investments. However, they emphasized the size of the company as the main indicator influencing the company's choice when deciding on the choice of investment criteria. For instance, the results of their research indicated that large firms were significantly more likely to use net present value techniques for project evaluation in comparison to small firms, while small firms used more frequently the payback criterion when evaluating investment projects. Furthermore, the results showed that small firms are also less likely to use sophisticated techniques such as sensitivity and VaR (value at risk) analyses. Regarding the cost of capital, the results showed that large firms were more inclined to use the CAPM (Capital Assets Pricing Model) in comparison to small firms, while the cost of capital for smaller firms was determined by 'what investors tell them that they need'.

Furthermore, Scott (2006) et al. tackled the same issue. They used the data obtained from the National Federation of Independent Business to analyze the capital budgeting practices of small firms (firms with fewer than 250 employees) in the United States of America (USA). The results indicated the same trend as the previous survey. Large firms tended to rely on the discounted cash flow analysis, while small firms evaluated projects using the payback period. The authors emphasized the limited education background of some business owners and small staff sizes to be one of the main reasons for rare usage of sophisticated project evaluation techniques. However, the survey indicated that liquidity concerns and cash flow estimation challenges appeared to be one of the key reasons as to why small firms did not frequently use discounted cash flow analysis in project evaluation.

Brounen et al. (2004) did the similar survey in Europe. The surrvey included 313 European CFOs regarding the issues such are capital budgeting, cost of capital, capital structure and corporate governance. Regarding the firm size, the results indicated that the larger firms most frequently used discounted cash flow methods when evaluating projects and applied the CAPM when determining the cost of capital. On the other hand, smaller firms were more inclined to estimate their investment opportunities by using the payback criterion and setting their cost of capital at whatever level their investors tell them. The results were similar to the results acquired from CFOs in the USA.

Finally, the authors Andor et al. (2011) conveyed the survey including the executives of companies in ten countries in Central and Eastern Europe (CEE) - Bulgaria, Croatia, the Czech Republic, Hungary, Latvia, Lithuania, Poland, Romania, Slovak Republic, and Slovenia. The survey itself tackled the issue regarding the companies' capital budgeting practices. The results clearly pointed out that implementation of capital budgeting methods was mostly influenced by the size of a firm. The outcome of the survey positively correlates with the results obtained from the executive bodies in the USA and Europe. Large companies and multinational firms are more inclined to use DCF (discounted cash flow analysis), for instance NPV (net present value) and IRR methods (internal rate of return) and more sophisticated techniques such as sensitivity and real option analyses unlike smaller firms. Additionally, large companies were more frequently using the CAPM as a method of estimating the cost of equity. Smaller firms again adjusted the cost of capital to the investors' requirements.

The latter survey, which was conducted in CEE countries, presents the benchmark for our survey, bearing in mind the resemblance regarding the similar historical heritage and the necessity for conveying additional financial, legislative and other reforms. The latter positions the harmonization of institutional framework of ex-communist countries with institutional frameworks of the countries from Western Europe as the primary goal. Some of the CEE countries have already successfully or less successfully completed the transitional period. Serbia has been experiencing such reforms for over a decade and may learn from the best practices of the countries in the region.

\section{METHODOLOGY}

By using contemporary finance literature, the authors have created the questionnaire comprising four sections: capital budgeting techniques and cost of capital, capital structure and pecking order theory, dividend policy and enterprise risk management concept (ERM concept). This paper focuses on two areas and thus, the first section of the questionnaire: capital budgeting techniques and the cost of capital. Furthermore, this 
paper tackles the issue of capital budgeting methods and cost of capital regarding small, medium and micro enterprises. The model for creating our questionnaire was the questionnaire used in the survey conveyed by Graham and Harvey in 2001 in the United States of America (USA) and Canada. The sample consisted of 4,440 firms and 392 chief financial officers that participated in the survey, with a response rate of $9 \%$.

It is important to emphasize that our paper presents only results relating to the first part of the questionnaire. Although our questionnaire includes 45 questions, the first section that relates to capital budgeting techniques and the cost of capital has only 10 questions. The respondents were asked about how often they use various capital budgeting techniques when evaluating whether they should accept or reject a project. They had to rate the frequency by using a scale of 1 to 5 (1 meaning "never", 5 meaning "always"). Additionally, the respondents were asked whether they have an investment and development policy. They also had to answer if they make business plans and do projections of cash flows before making an investment decision. Furthermore, the ways of calculating the project's cost of capital are the focus of this part of the questionnaire. The respondents had to rate the frequency of implementing each method (CAPM, discounted dividend model etc.) using a 5-point scale (1 meaning "never", 5 meaning "always"). Finally, the last part of the first section measures the frequency of risk adjustments of the discount rate and cash flows. The same method is used, i.e. the CFOs had to describe the frequency of taking each risk factor into consideration for cash flow and discount rate adjustments. The draft of the questionnaire was sent to financial analysts and experts for reviewing before sending it to the respondents and was approved by them. The questionnaires were then sent to CFOs by mail. In addition, we offered an option to call the respondents by phone in case of ambiguities so as to diminish the possibility of incorrect or biased answers.

For the purpose of this research, the sample included 30 companies. Out of the overall number, 13 enterprises present micro companies, 8 enterprises are defined as small enterprises and 10 companies are defined as medium-sized enterprises following the classification defined in the Law and Accounting. ${ }^{1}$ Furthermore, the analysis of the ownership shows that $20 \%$ of the companies within the sample are foreign and $80 \%$ are domestic firms. In the end,

1 According to the Law on Accounting and auditing the enterprises are classified into the following categories:

Micro: (annual average number of employees $\leq 10$; annual sales $\leq$ 84,671,000 RSD and annual average asset value $\leq 42,335,000 \mathrm{RSD})$; Small: (10 $\leq$ annual average number of employees $\leq 50 ; 84,671,000$ $\mathrm{RSD} \leq$ annual sales $\leq 1,064,433,000$ RSD; 42,335,000 RSD $\leq$ annual average asset value $\leq 532,217,000$ RSD);

Medium: $(50 \leq$ annual average number of employees $\leq 250$; $1,064,433,000$ RSD $\leq$ annual sales $\leq 4,233,541,000$ RSD; 532,217, 000 RSD $\leq$ annual average asset value $\leq 2,116,770,000)$;

Large: (annual average number of employees $\geq 250$; annual sales
$30 \%$ of firms in our sample consisting of all three categories are manufacturers. The non-manufacturing firms are equally distributed across other industries: retail and wholesale (25\%), tourism and hotels (20\%), agriculture $10 \%$, telecommunication (5\%), IT sector (5\%) and consulting companies (5\%). Finally, the answers were processed in SPSS statistical program and the results are presented in the following section.

\section{RESULTS}

This section provides the results of the analysis herein conducted. This section will be structured as follows. Within the first part, we test our first hypothesis regarding the fact that micro, small and medium-sized companies in Serbia use payback criterion as the most dominant investment evaluation technique. In the second part, the second hypothesis is tested referring to the fact that micro, small and mediumsized companies in Serbia are more inclined to determine the cost of capital following the historical returns on investments.

The results referring to the choice of investment criterion given by small, medium-sized and micro enterprises are summarized in Figure 1. Figure 1. Percent of respondents (CFOs) who always or often use given capital budgeting
techniques
Source: Results from the survey conveyed by the authors
Our analysis aimed to identify most frequently used capital budgeting techniques in SMEs and micro companies in Serbia. Seven capital budgeting techniques are offered in the questionnaire: NPV (net present value), IRR (internal rate of return), PI (profitability index), PP (payback criterion), ARR (accounting rate of return), DPP (discounted payback criterion) and SA (sensitivity analysis) and the respondents had to rate the frequency of their usage from 1 to 5 . The results showed that the SMEs and micro companies were most inclined to use payback criterion as the capital budgeting technique (the average percent of usage regarding this technique by all three types of the companies was $68.8 \%$ ). Furthermore, the results showed that $58 \%$ of the companies most frequently used PI and $42 \%$ of the respondents used $\mathrm{NPV}$ as the investment criterion in project evaluation (once 
again the averages were taken into consideration). In the interviews that in some cases followed the questionnaire, the respondents stated that less frequent implementation of discounted cash flow techniques was mostly influenced by the inability to determine discount rate, due to inefficient capital market in Serbia. Having in mind that the determination of discount rate involves finding the expected rate of return for the investments that bear the same level of risk as our investments, inefficient capital market may be perceived as the crucial obstacle for successful implementation of discounted cash flow techniques. On the other hand, payback criterion is the technique that does not take into account time value of money, avoiding the problem of finding the appropriate discount rate. Moreover, some of the respondents stated that the limited education background of some business owners and small staff sizes contributed to insufficient use of sophisticated project evaluation techniques in small firms. Finally, the results showed that the small companies in Serbia use payback criterion as the most dominant investment evaluation technique, thus supporting the first hypothesis herein presented.

Furthermore, the second part of our analysis is directed towards testing the hypothesis related to the costs of capital stating that the micro, small and medium-sized companies in Serbia are more inclined to determine the cost of capital following the historical returns on investments. The results are presented in the following figure.

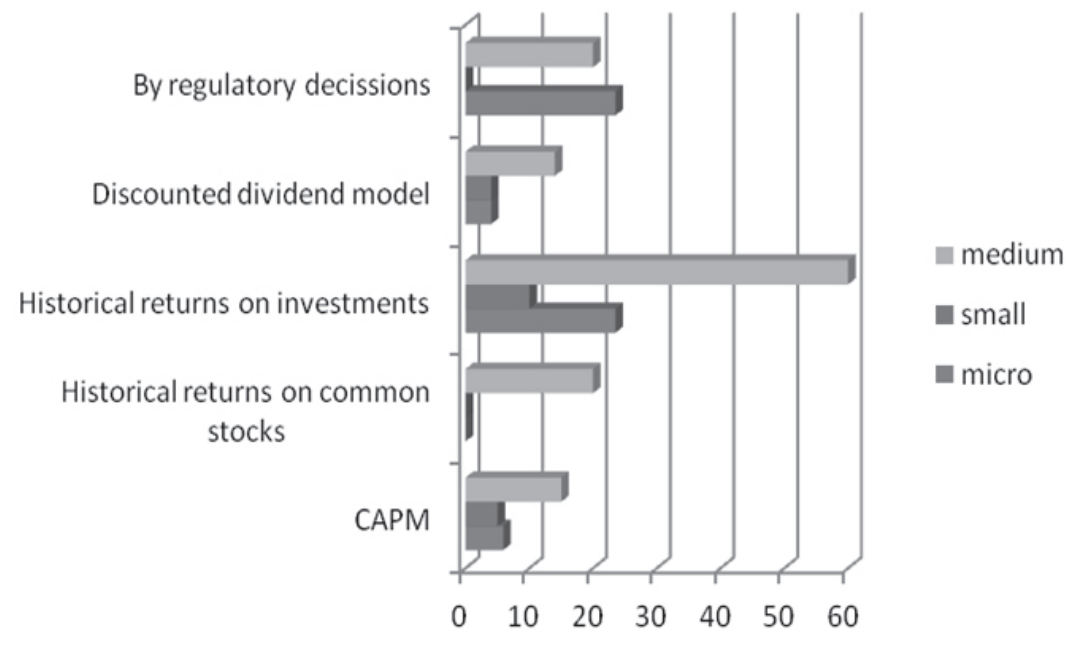

Figure 2. Percent of CFOs who always and often use a given method Source: Results from the survey conveyed by the authors (with average value of $8 \%$ ). The most frequent answer regarding the rare usage of CAPM was once again the fact regarding inefficient capital market. However, it is crucial to emphasize that most of the sampled companies are private firms and their beta could only be calculated through analyzing comparable publicly traded companies, which is a great challenge in Serbia due to the inefficient and illiquid capital market. The capital market in Serbia is not efficient and liquid in comparison to capital markets in the USA and Europe, which is the key obstacle to implementing the CAPM in Serbian companies. Once again, the general lack of knowledge regarding contemporary financial concept appears to be an issue once again. However, the gap between the theory and practice is widened, mostly due to the lack of effective andefficient financial environment in Serbia. Even though the laws regulating the financial system in Serbia do exist and are well defined in theory, their actual implementation is lacking. The average historical rate of return on their investments appeared to be the most easily comprehensible technique implemented by the companies. However, calculating the cost of capital represents an important step when determining the feasibility of investments and its calculation should be taken very seriously. Its calculation directly affects the final decision regarding the acceptance or rejection of investments. If the company does not perceive the risk regarding the investment in its full size, it may lead to unrealistic projection regarding the cash flow of the project that may mislead the investor to accept the unprofitable project. Within the conditions of economic turmoil and general illiquidity, the money spent on a particular project would be thrown away without giving the second chance to spend it more wisely by accepting other investments. This could be particularly observed in smaller firms. Even though most of the companies stated that they had well defined investment policy and business plan and did regularly cash flow projections regarding new investments (average rate of responses was $89 \%$, $82 \%$ and $94 \%$ ), its actual implementation in everyday business life was pointless without determining the accurate number regarding the cost of capital. Finally, the second hypothesis is confirmed stating that the micro, small and medium-sized companies in Serbia are more inclined to determine the cost of capital following historical returns on investments.
If we analyze the results presented in the Figure 2, it is noticeable that the most frequent criterion implemented by the companies is historical return on investments with an average value for all 3 types of the companies amounting to $32 \%$. The medium-sized companies were the most inclined to use this method (60\% of the respondents stated that they always and often used this method) when evaluating the cost of capital for their investments. The cost of capital determined by regulatory decisions was the second most used method for determining the cost of capital (average for all the companies from the sample amounting to $15 \%)$. The results showed that implementation of CAPM (Capital Asset Pricing Model) by the sampled companies was rather rare

\section{CONCLUSION}

The aim of this paper is to determine the most frequently used capital budgeting technique by SMEs and micro companies in Serbia upon project evaluation and the most frequent way of calculating the cost of capital. Consequently, two hypotheses were tested. The first hypothesis stated that micro, small and medium-sized companies in Serbia used payback criterion as the most dominant investment evaluation technique. The second hypothesis was tested within the second part of the paper referring to the fact that micro, small and medium-sized companies in Serbia are most inclined to determine the cost of capital following historical returns on investments. In order to test previously mentioned 
hypotheses, the authors conveyed the survey comprising 30 companies (small, medium and micro companies following the classification presented within the Law on Accounting and Auditing). The results revealed the fact that the most prevailing investment technique was payback criterion and the most frequent way for calculating cost of capital was historical return on investments. The respondents answered that lack of education and inefficient capital market were the main reasons influencing the rare usage of more sophisticated techniques when evaluating project and determining the cost of capital. This raises again the issue regarding the initialization of various programs, workshops, seminars that will familiarize the public with all the relevant techniques, , as well as providing adequate business environment where those concepts could actually be implemented. Consequently, the companies would be able to implement more sophisticated techniques regarding both the capital budgeting techniques and cost of capital. The results emphasized the need for further reforms regarding the Serbian financial system and harmonization with EU level, especially within the process of EU integration. The reform of the financial systems and improvement of its efficiency and soundness may be one of the key priorities in the following period especially bearing in mind its importance for achieving financial inclusion of small and medium firms, emphasized within the document Europe 2020. However, further education of both employers and employees within the small firms may be a valuable instrument for achieving those goals. However, the Government should enable them a healthy competitive business environment that would offer equal conditions for all market players, without favoring of any side. The sound and efficient financial system may contribute to frequent usage of more sophisticated investment techniques by SMEs apart from payback criterion, consequently leading to more sustainable investments that may contribute to the economic growth on the macro level.

\section{REFERENCES}

Andor, G., Mohanty, S., \& Toth, T. (2011). Capital budgeting practices: a survey of Central and Eastern European firms. Emerging Markets Review, 23, 148-172. doi:10.1016/j.ememar.2015.04.002

Brounen, D., Jong, A., \& Koedijk, K. (2004). Corporate Finance in Europe: Confronting Theory with Practice. Financial Management, 33(4), 71-101.

Danielson, M., \& Scott, J. (2006). The Capital Budgeting Decisions of Small Businesses. Journal of Applied Finance, 16(2), 45-56.

Erić, D., Beraha, I., Đuričin, S., Kecman, N., \& Jakišić, B. (2012). SMEs financing in Serbia. Retrieved October 18, 2015 from http://www.pks.rs/SADRZAJ/Files/Biro\%20za\%20saradnju\%20 sa\%20EU/Finansiranje\%20MSP\%20u\%20Srbiji.pdf

European Commission. (2010). Europe 2020: A strategy for smart, sustainable and inclusive growth. Retrieved October 18, 2015 from http://ec.europa.eu/eu2020/pdf/COMPLET\%20EN\%20BARROSO\%20\%20\%20007\%20-\%20Europe $\% 202020 \% 20-\% 20$ EN\%20version.pdf

European Commission. (2003). Commission Recommendation 2003/361/EC of 6 May 2003. Retrieved October 18, 2015 from http://eur-lex.europa.eu/legal-content/EN/ TXT/?uri=URISERV:n26026

Graham, J., \& Harvey C. (2001). The theory and practice of corporate finance: evidence from the field. Journal of $\mathrm{Fi}$ nancial Economics, 60(2-3), 187-243. doi:10.1016/S0304405X(01)00044-7

Statistical Office of the Republic of Serbia. (2015). Labor Force Survey 2015. Retrieved October 18, 2015 from http://webrzs.stat.gov.rs/WebSite/repository/documents/00/01/90/10/ RS10_284_II_kvartal_srb-2015.pdf.

Young, L. (2015). The Report on the Small Firms 2010-2015 for UK. Retrieved October 15, 2015 from https://www.gov.uk/ government/uploads/system/uploads/attachment_data/ file/402897/Lord_Young_s_enterprise_report-web_version_final.pdf

\section{ANALIZA METODA VREDNOVANJA PROJEKATA NA PRIMERU MALIH I SREDNJIH PREDUZEĆA U SRBIJI}

\begin{abstract}
Apstrakt:
U radu se ispituju metode vrednovanja projekata na primeru 30 malih i srednjih preduzeća u Srbiji. Uzorak je obuhvatio mala i srednja preduzeća kao i mikro kompanije. Za potrebe istraživanja korišćen je upitnik koji su popunjavali finansijski direktori.

Mala i srednja preduzeća igraju veliku ulogu u ekonomskom razvoju jedne zemlje i ujedno predstavljaju glavni pokretač privrednog rasta u EU. Stoga, cilj ovog rada jeste da ispita njihovu ulogu u Srbiji, njihov doprinos smanjenju stope nezaposlenosti, kao i investicije koje su posmatrane kompanije realizovale tokom proteklih godina. Takođe, istraživanje stavlja naglasak na analizu metoda vrednovanja projekata koje koristi ovaj tip kompanija prilikom donošenja investicionih odluka. U radu se ističe i značaj jasno definisane investicione politike kao preduslov za odabir profitabilnih i dugoročno održivih investicija bez kojih nema ni rasta ni razvoja, kako na mikro tako i na makro nivou, a upravo implementacija investicionih kriterijuma doprinosi pomenutom cilju. Proces donošenja investicionih odluka u svakodnevnom poslovanju jeste predmet ovog rada, posebno u uslovima opšte nelikvidnosti u zemlji. Na samom kraju ističe se neophodnost postojanja jasno definisane investicione politike preduzeća zajedno sa implementiranim metodama vrednovanja projekata, kako bi se ostvarila uspešna i dugoročna održivost investicija koje bi doprinele jačanju uloge malih i srednjih preduzeća kao ključnih pokretača privrede u zemlji.
\end{abstract}

\section{Ključne reči:}

investiciona politika, privredni rast, mala i srednja preduzeća, metode vrednovanja projekata. 